MUZIKOLOŠKI ZBORNIK - MUSICOLOGICAL ANNUAL XIV, LJUBLJANA 1979

UDK 785.74:787.1/.4 Slavenski

\title{
TEMATSKA STRUKTURA U PRVOM GUDAČKOM KVARTETU JOSIPA SLAVENSKOG
}

\author{
Bojan Bujić (Oxford)
}

\begin{abstract}
"On (Adrian Leverkühn) se držao po strani dijeleći samo $u$ trenutcima opuštanja sa mnom svoja razmišljanja, govoreći osobito o problemima jedinstva, mogućnosti izmjenjivanja, podudarnosti horizontalnog i vertikalnog pisanja. Ubrzo je imao, kako se meni činilo, nadnaravnu moć pronalaženja melodijskih linija koje su se mogle simultano postaviti jedna protiv druge, čiji bi se tonovi uklopili u kompleksne harmonije - a s druge strane, pronalazio je akorde što su sadržavali skupine tonova koji su mogli biti projicirani u melodijsku horizontalu."
\end{abstract}

(Thomas Mann: Doktor Faust, gl. IX)

Odnos jugoslavenske muzikologije, ili bolje rečeno muzičke publicistike, prema opusu Josipa Slavenskog je već dobro poznat fenomen $u$ našoj novijoj kulturnoj historiji: kompozitor je za života jedno vrijeme bio ignorisan a potom je, nakon njegove smrti, nastupio period kada je nekritički prihvatano sve što je napisao. Niko, pa niti najodaniji poštovaoci Slavenskog ne mogu, međutim, poreći činjenicu da je njegov opus nejednake vrijednosti. Jugoslavenska muzikologija se može odužiti Slavenskom ako mu umjesto emocionalnih fraza pokloni dužno poštovanje da se pozabavi njegovim djelima. Oni kojima je na srcu muzika Slavenskog i ono što je u njoj najbolje, mogu samo biti ohrabreni saznanjem da se počeo stvarati fond analitičke literature o toj muzici, te da se $u$ radovima o Slavenskom umjesto dosadašnjeg memoarskog i esejističkog stila sve češce opaža pristup kritičkog vrednovanja. ${ }^{1}$ Cilj ovog rada je da dâ prilog

1 Usp.: Seadeta Midžić, Klavirska djela Josipa Slavenskog, Zvuk, br. 81, 1968, str. 12. Eva Sedak, Zvučno okružje glazbe Josipa Slavenskog, Radio-Sarajevo: Treći program, V/15, oktobar-decembar 1976, str. 352. Gorana Dolinar, Djelo Josipa Slavenskog $u$ poređenju sa karakteristikama ekspresionističkog stila $u$ muzici, ibid., str. 365. Mirjana Živković, Neke osobine harmonskog jezika Josipa Slavenskog, ibid., str. 377. 
toj vrsti pristupa iako je autor svjestan ograničenja koje je teško premostiti u ovom času: za iscrpnu analizu jedne nedovoljno poznate kompozicije potrebno je da čitalac ima pri ruci njenu partituru, no nju, razumljivo, nije moguce reproducirati u okvirima jednog članka u časopisu. Cak i izabrani notni primjeri mogu biti tek nepotpuna ilustracija svog onog mnoštva detalja na koje je potrebno ukazati da bi se $u$ analitičkom smislu prikazao unutrašnji život jedne kompozicije. Razmatranje koje slijedi treba zato uzeti ne kao definitivni sud o djelu nego kao ilustraciju jednog od mogućih pristupa shvatanju kompozicije koja ima naročito mjesto $u$ jugoslavenskoj muzici dvadesetog stoljeća.

Prvi gudački kvartet Josipa Slavenskog je prije više od pola stoljeća donio svome autoru međunarodno priznanje a za jugoslavensku muziku je značio obogaćenje jednim značajnim djelom koje je uspjelo da ujedini prizvuk južnoslavenskog folklornog idioma sa kompozicionim procesom jednog dijela tadašnje evropske avangarde. Nemoguće je sada tačno utvrditi kada je ovaj kvartet nastao. Već 1920. godine Janko Barlè spominje u jednom popisu radova mladog Slavenskog da su mu opusi 3. i 4 . gudački kvarteti. ${ }^{2}$ Kasnije je kao op. 4, naravno, obilježena Sonata za klavir, dok je Prvi gudački kvartet zaista ostao op. 3. Možda su to u vrijeme Barlèovog pisanja bile samo skice, koje su kasnije, $u$ vrijeme studija $u$ Pragu, u klasi V. Nováka, dotjerane i dovršene. Kvartet je bio izveden prvi put u Pragu na diplomskom koncertu studenata Majstorske škole Konzervatorija, 26. juna 1923. godine. Kasnije te iste godine, 26. oktobra, Kvartet su u Zagrebu izveli članovi Zagrebačkog kvarteta u okviru Četvrte intimne večeri Hrvatskog glazbenog zavoda. Nakon ovoga slijedi $u$ augustu 1924. godine dobro poznata izvedba na festivalu savremene muzike $u$ Donaueschingenu. Kvartet Slavenskog našao se tada na programu uz djela Maxa Buttinga (Kleine Stücke op. 26) i Antona Weberna (Sechs Bagatellen op. 9 za gudački kvartet i Sechs Lieder op. 14 na tekstove G. Trakla). Kao što je poznato, uspjeh Kvarteta na tom koncertu zainteresirao je za Slavenskog izdavačku kuću Schott koja je 1925. godine sklopila s njim ugovor o izdavanju Kvarteta, kao i ranijih i buduciih djela. ${ }^{3}$ Džepna partitura Kvarteta izdana je 1926. godine pod kataloškim brojem $3461 .^{4}$

2 Janko Barlè, Josip Štolcer, Sveta Cecilija, XIV/4, 1920, str. 86.

${ }_{3}^{3}$ Podrobnije o ovome vidi $\mathrm{u}$ : Milana Slavenski, Veze josipa Slavenskog $s$ muzičkom izdavačkom kućom B. Schott's Söhne, Mainz, Zvuk, br. 109-110, 1970 str. 437.

${ }^{4}$ Prije nekoliko godina vođena je sasvim nepotrebna polemika između Milane Slavenski (vidi fusnotu 3) i Milana Grafa (Objašnjenje meobjašnjivih lapsusa", Zvuk, br. 119-120, 1971, str. 459) oko toga da li je Zagrebački kvartet izvodio Slavenskog iz štampanih ili rukopisnih dionica. Milana Slavenski nema pravo kada tvrdi da Prvi i Drugi kvartet nisu mogli biti drugačije izvođeni nego iz izdanja Schott iz jednostavnog razloga što su izvedbe oba Kvarteta prethodile izdavanju partitura. Milan Graf, pozivajući se na očigledno pogrešnu informaciju iz kuće Schott, čak izražava sumnju da je Drugi („Lirskii) kvartet ikada i izdan (v. Graf, ibid., str. 464.). Da bi se otklonila eventualna ponovna slična nagađanja, treba istaknuti da je partitura Drugog kvarteta izdana od Schotta 1930. godine pod kataloškim brojem 3490 . 
Ako ikada dođe do pripremanja kritičkog izdanja kompletnog opusa Slavenskog, za što se $\mathbf{s}$ pravom zalaže Gorana Dolinar, ${ }^{5}$ tekst Kvarteta ce, kao uostalom i mnoga druga djela, predstavljati izvjestan problem. Na programı praškog diplomskog koncerta dva stavka Kvarteta nose oznake: Fuga. Largo i Jugoslávský tanec. Allegro molto (v sonatové formě). Na zagrebačkım programu stoji Largo molto intensivo i Jugoslavenski ples. Allegro molto vivace. Stampana partitura ima oznake Pevanje. Largo molto intensivo (con dinamica spontana) i Igranje (Südslawischer Tanz). Andante deciso - Allegro balcanico. Bez uvida u autograf nemoguće je sada reći da li nisu u periodu 1923.-25. osim oznaka tempa unesene i neke druge važnije tekstovne promjene. Štampana partitura nosi napomenu Revu et édité par J. Kilp. Kakva je bila uloga ovog urednika i da li se ograničila na oznake poteza gudala? Ovi su zaista naznačeni skrupulozno i znalački, a uz to je u oba stavka precizno označena dinamika. Bilo bi zanimljivo znati kolika je u ovome uloga članova Zagrebačkog kvarteta koji su, prema Milanu Grafu, imali priličnog udjela u dotjerivanju detalja partiture. ${ }^{6}$ Detaljne i obilne dinamičke oznake stoje, tako, u prvom stavku u kontradikciji sa oznakom con dinamica spontana, i možda ih je moguce objasniti kao intervenciju urednika. Odgovore na ova pitanja možda bi mogle pružiti rukopisne dionice iz kojih je svirao Zagrebački kvartet i iz kojih je ponešto mogao preuzeti i Schottov urednik Kilp.

Iako je pred nama jedan studentski diplomski rad, ostaje i danas neosporna činjenca, na koju su ukazali i prvi kritičari Kvarteta, da je to djelo puno koncentrirane energije i da pokazuje solidno vladanje kompozicionom tehnikom. Kvartet nesumnjivo spada $u$ onaj tip diplomskih radova koji su to samo po imenu, poput djela Glazunova ili Šostakoviča nastalih za slične prilike. Neizbježno se nameće pitanje o mogućim uzorima ili djelima uz koje bi se ovaj kvartet dao svrstati kao jedan od predstavnika novog nacionalnog stila koji je uz različite regionalne modifikacije nastajao na teritoriji Austro-Ugarske monarhije $u$ vrijeme ili neposredno nakon njenog raspada. Nekritičko ponavljanje tvrdnji o izvornosti i potpunoj neovisnosti Slavenskog od bilo kakvih vanjskih uzora izgleda da je onemogućilo neke od ranijih kompozitorovih apologeta da opaze očigledni afinitet koji postoji između njegovih ranih klavirskih kompozicija i Bartókovih djela nastalih neposredno pred Prvi svjetski rat. ${ }^{7}$ Priznavanje ove činjenice ne umanjuje originalnost Slavenskog, nego bolje određuje njegovu pripadnost, barem $u$ to vrijeme, jednom kulturnom krugu u kojem su Bartók i Kodály, čiji je učenik Slavenski bio između 1913. i 1916., bile značajne ličnosti. Uostalom, Kvartet Slavenskog pokazuje površnu, iako ne beznačajnu, sličnost sa Drugim gudačkim kvartetom op. 10, Zoltána Kodályja, koji je napisan 1918. a objavljen 1921. godine

Gorana Dolinar, ibid., str. 375.

- Usp. M. Graf, ibid., str. 461.

7 Upadljiva sličnost postoji, na primjer, između pojedinih kompozicija iz zbirki Iz Jugoslavije i Jugoslavenske svite, op. $2 \mathrm{~s}$ jedne strane, i Bartókovih Cetrnaest bagatela op. 6 iz 1908: godine, s druge. 
i sasvim je moguće da ga je Slavenski ili čuo ili vidio $u$ partituri $u$ vrijeme studija u Pragu. Sada bi se moglo samo nagađati nije li ga upravo Kodályjev kvartet ponukao da do kraja izradi ili preinači skice za kvartet koje je imao od ranije i koje spominje Janko Barlè kao »kvartet op. 3«. Nije isključeno da je Slavenski preuzeo od Kodályja neke vanjske okvire kvarteta: oba kvarteta imaju po dva stavka, iako su Kodályjevi nešto razvijeniji. Tonalni centar Kodályjevog Kvarteta je $D$ sa pojačanom važnošću $A$ na početku drugog stavka, centar prvog stavka Slavenskog je $D$, drugog $A$. Drugi stavci obiju kvarteta su pretežno plesnog karaktera

s akcentom na ritmičkoj figuri $\underset{4}{2}$ गJ्ग . Za prvi stavak Kodályjevog

Kvarteta karakterističan je improvizatorski elemenat, naglašen uputom: Der erste Satz ist sehr fliessend, ohne besondere Betonung der Taktschwerpunkte vorzutragen, ${ }^{3}$ dok Slavenski prepušta dinamiku izvođačima kao spontani elemenat. Još neke sličnosti koje se mogu opaziti svode se uglavnom na karakteristike melodijskog idioma i daju se objasniti kompozitorovom sviješću o pripadnosti određenom stilu. U svakom drugom pogledu Kvartet Slavenskog ima svoju specifičnu logiku.

Poteškoće s kojima se sreće analitičar jednog djela čija je glavna karakteristika stil na graničnom području između tonalnosti, modalnosti i slobodne atonalnosti, nastaju već kod izbora adekvatne terminologije i nastavljaju se kod pokušaja određenja analitičkog procesa. Utvrđivanje sličnosti formi koje stavci kvarteta pokazuju u odnosu na standardne klasifikacije zasnovane na principima klasične muzike otkriva samo jedan površinski detalj, a ostavlja neotkriveno bogastvo konstruktivnih principa koji formu stvaraju iznutra. Istina je da prvi stav Kvarteta pokazuje obrise fuge, kao što drugi stav pokazuje obrise sonatne forme, no insistirati na ovakvom opisu znači prići Kvartetu sa unaprijed fiksiranim formalnim shemama, pa u njemu onda tražiti eventualne devijacije. Poći ćemo zato od nekih karakteristika pređnjeg sloja i nastojati zaključiti do koje mjere one prodiru $u$ dubinu muzičke strukture.

\section{Prvi stavak (I)}

Raniji komentatori ovog kvarteta su se, kako se može i očekivati, zaustavljali na vanjskim odlikama teme kojom počinje fugirana ekspozicija prvog stavka. Tako je bila istaknuta njena ekspresivnost, široki opseg, dugački razvojni luk.' Ove opservacije, koliko god bile tačne, nemaju značaja $u$ razmatranju strukturne važnosti teme u sklopu čitavog djela. Treba zato poći od njene motivičke i tonalne strukture.

Početni tonovi teme tvore jedan melodijski obrazac (označen kao $x$, Pr. 1a) koji će u čitavom djelu odigrati izuzetno značajnu ulogu. Ostatak teme je $u$ kasnijem razvoju melodijski od nešto manjeg značaja u usporedbi sa $x$, ali zato doprinosi izgradnji jednog drugog obrasca, od vitalnog značaja za strukturu Kvarteta. Pridavajući posebnu važnost tonovima koji

- Zoltán Kodály: Streichquartett II, Philharmonia Partituren, No. 602.

${ }^{9}$ Usp. Josip Andreis, Music in Croatia, Zagreb 1974, str. 305. 


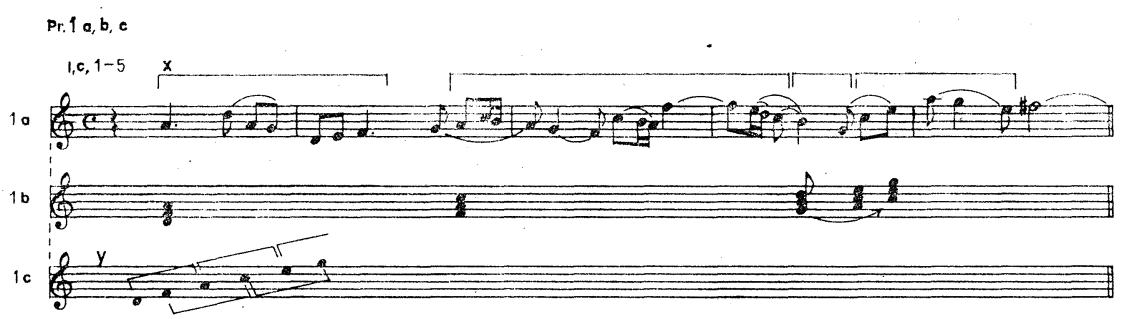

po svojoj registraciji, položaju unutar motiva i duljini trajanja izbivaju kao važniji u jednom hijerarhijskom redu, može se uočiti da je tema razvijena iz nekoliko trozvuka čija je tendencija visinske registracije uzlazna, kao uostalom i tendencija čitave teme. Početni trozvuk $D-F-A$ je osim toga tonalni centar kompozicije. Zanimljiva je situacija u I, c, 4 gdje tonovi $H$ i $G u$ jednom času uspostavljaju kauzalnu vezu sa $C$ i $E$, no ulaskom najvišeg tona fraze $A$ u I, c, 5 stvara se ambivalentnost između trozvuka $A-C-E$ i $C-G-E$ (Pr. 1b). Ovaj momenat, nagoviješten na samom početku kompozicije dobiva tek $u$ njenom toku svoju logičku dopunu. Smatrajući za sada trozvuk G-H-D samo prolaznim događajem sekundarne vrijednosti u sklopu teme, vidimo da tonovi preostalih trozvuka tvore jedan melodijski niz (model $y$ ) koji $u$ sebi sadrži četiri potpuna trozvuka i nagoviještenu ali neispunjenu mogućnost petog (pr. 1c). Potrebno je insistirati na ovakvoj linearnoj karakterizaciji teme jer je ona bez sudjelovanja drugih glasova prvi karakteristični slušni elemenat kompozicije. Drugi karakteristični elemenat nastupa $u$ momentu prve vertikalne kombinacije u I, c-d, 5 (pr. 2a). Nakon što je na čas zazvučala terca $E$-G, kombinacija vertikalnog i horizontalnog zvučanja daje niz tonova $D$-E-Fis.A (model $z$, pr. $2 b$ ). Istina je da je $D$ najdublji ton, te uz to odgovara $i$ tonalnom centru početne teme, ali unisono viole i violoncella daje tonu $E$ posebnu važnost pa se tako može izvesti i derivat modela $z: z^{1}$ (pr. 2c). Redukcijom početnog motiva $(x)$ na njegov osnovni obris dobiva se figura $A-D-A-D$, koja je samo neznatno proširena figura uzlazne kvinte i kvarte (pr. 3a). Ovakve figure, ili bolje rečeno modeli, se često sreću u muzici Bartóka, Kodályja, te Slavenskog i mnogih drugih jugoslavenskih kompozitora nacionalne orijentacije $u$ dvadesetim $i$ tridesetim godinama ovog stoljeća. Uloga im je donekle ilustrativna jer podsjeća na inarodni" stil muziciranja, dok je njihova konstruktivna primjena vrlo ograničena zbog ograničenog broja derivacija koje se iz modela mogu postici. Slavenski upotrebljava ovakve figure i kao konstruktivne i kao ornamentalne elemente, naročito $u$ ranijim klavirskim kompozicijama, dok se $u$ Kvartetu pokazuje tendencija prevazilaženja njihove ograničenosti uvođenja jednog gornjeg susjednog tona koji ima ulogu prolongacije, ali ujedno otvara mogućnosti transpozicije naoko jednostavnog niza dvaju kvinti u nova tonska područja. (Pr. 3b, c.) Ovakav niz ima svoju paralelu već $u$ modelu $y$, te je samo logička posljedica mogućnosti zacrtanih u početnoj temi. Daljnji razvoj ovog principa rezultira melodijskim 

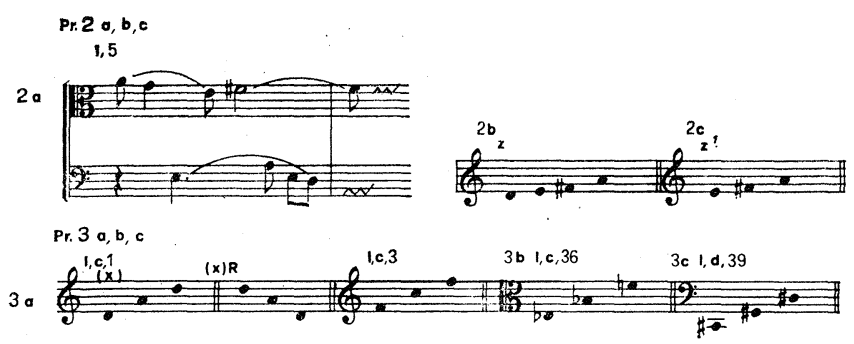

linijama koje su izvedene na osnovi izkomponiravanja, ${ }^{10}$ iz modela $y$, uz dopuštanje polustepenskih promjena na osnovnim tonovima modela (na primjer $G$ is umjesto $G \mathrm{u}$ pr. $5 \mathrm{~b}$ ). Dodatne varijacije i motivski rad nekad zasjenjuju konture modela $y$ (pr. 4a), te tako u prvi slušni plan izbijaju motivi izvedeni iz osnovne teme fuge (pr. $4 \mathrm{~b}, \mathrm{u}$ "durskoj« varijanti), dok se u stvari radi o suptilnom miješanju dvaju konstruktivnih elemenata od kojih jedan (model $y$ ) prelazi iz zadnjeg plana postepeno $u$ prednji

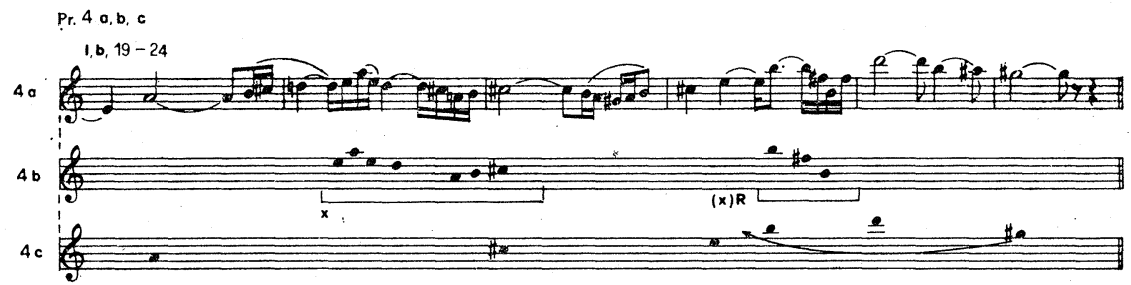

(pr. 4a, c). U I, b, 22 ukrasna figura $H-F i s-H-F i s$ pokazuje ne samo koliko važnosti pripada modelu iz pr. 3a, nego demonstrira i činjenicu, od presudne važnosti za cjelokupno harmonsko tkivo kvarteta, da gotovo svaki ton može postati $u$, datom momentu ishodištem novog trozvuka. Ovo je način na koji Slavenski prihvata i razvija princip pantonalnosti, a pridavajući jednim tonskim centrima privremenu važnost nad drugim, uspijeva da, kao u slučaju drugog stavka, izgradi kompleksnu harmonsku shemu, o čemu će biti riječi nešto kasnije. Sada treba, ne ispuštajući iz vida transformacije modela $y$, ukazati na njegovu ulogu $u$ formiranju značajne linije violoncella u I, d, 28-32 (pr. 5a). Ovakve gradacije, izvedene pomacima terci, sreću se u Slavenskoga i drugdje, a zanimljiv primjer

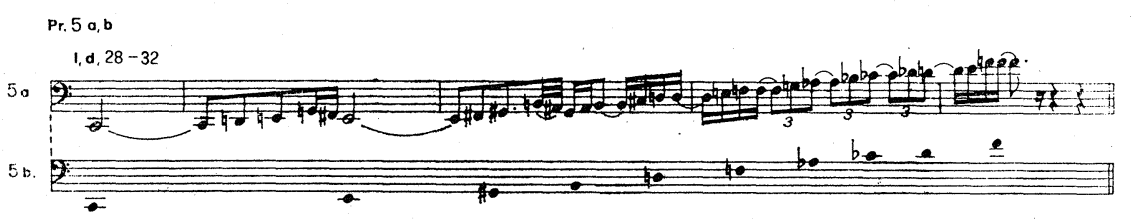

${ }^{10} \mathrm{U}$ nedostatku priznatog termina $\mathrm{u}$ srpskohrvatskoj muzikološkoj terminologiji usuđujem se da tako prevedem Schenkerov termin auskomponieren/Auskomponierung. 
nalazi se $\mathrm{u}$ djelu koje prethodi Kvartetu, $\mathrm{u}$ četvrtom stavku Jugoslavenske svite op. 2 (pr. 6). Terasasto pomicanje terci bilo je, naravno, poznato

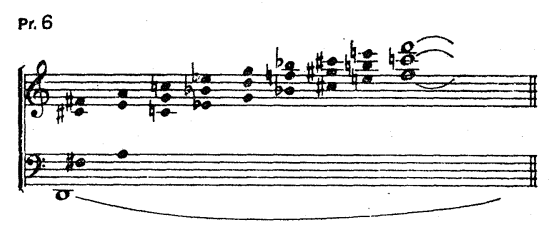

i prije Slavenskog. Liszt je taj princip upotrebljavao i kao harmonsku shemu i kao melodijski obrazac i od njega su ga preuzeli kompozitori
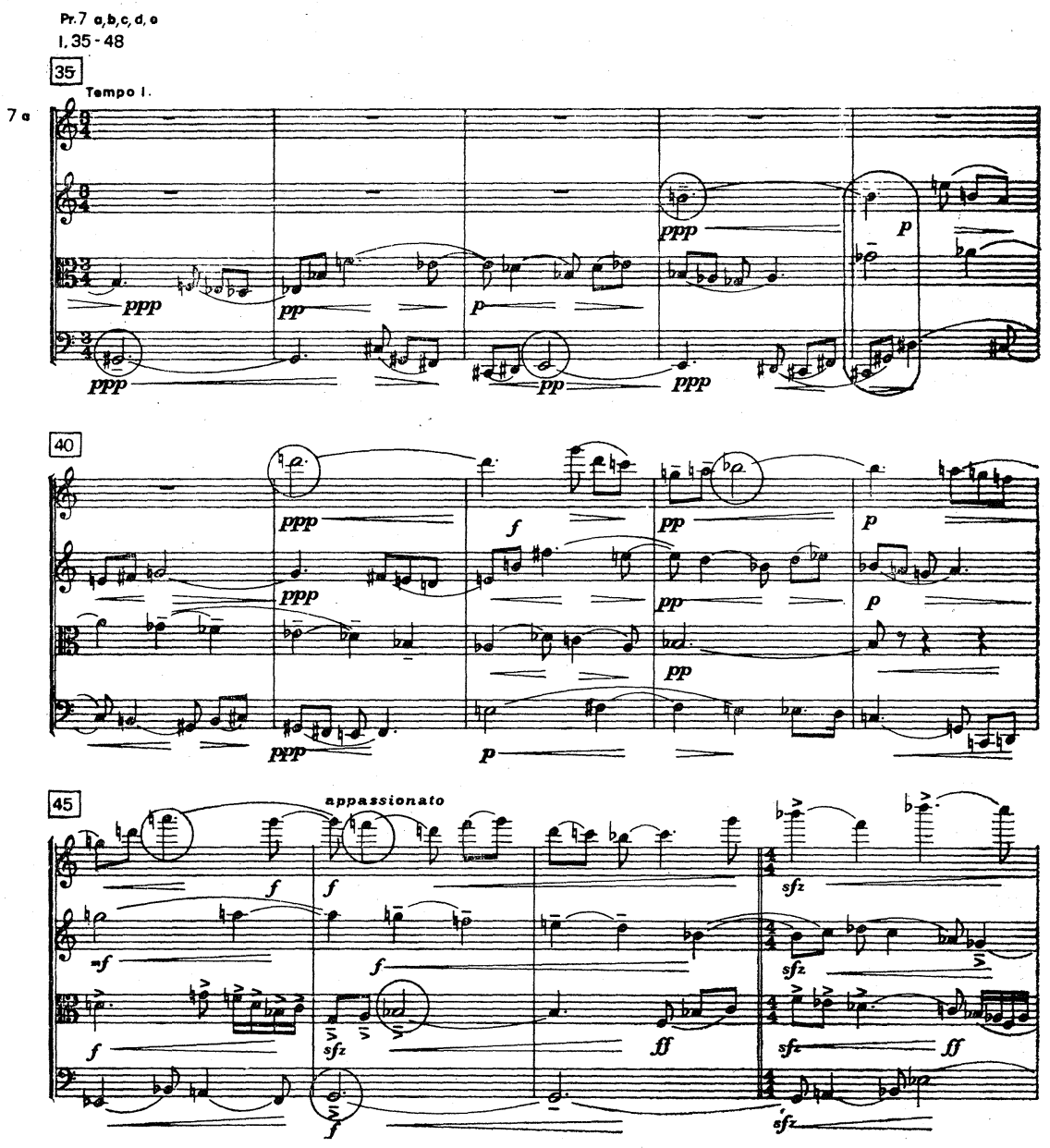
iz kruga ruske Petorice. ${ }^{11}$ Neosporan je $u$ tom pogledu i Lisztov uticaj na Bartóka. Zanimljivo je da su se u traženju novih mogućnosti za obogaćenje tonskog jezika, mnogi kompozitori porijeklom iz vrlo različitih kultura, okrenuli prema nizovima terci kao postupku koji, iako potiče iz trozvučne osnove, postiže efekat privremenog suspendovanja tonaliteta.12 Kod Slavenskog se često osjeća možda namjerno dvoumljenje između takve ne-tonalne funkcije nizova terci i primjene sklopova terci koje tvore akord sa tačno određenom tonalnom funkcijom $u$ sklopu čitave kompozicije. Unutrašnja napetost kompozicije je tako, zapravo, i postignuta neprestanim pomicanjem fokusa sa tonalnog funkcionalnog sklopa na tonske oblasti čija su ishodišta karakteristični tonovi tog sklopa. Kompleksnost takvih struktura je uz to još naglašena i postojanjem vremenske hijerarhije, to jest situacije gdje jedan proces koji traje nekoliko taktova augmentira drugi slični proces koji se javlja samo kao kratki prolazni događaj. Kao ilustracija ovoga mogu poslužiti taktovi I, 35-48 (pr. 7a). Odlomak je značajan i po tome što se nalazi na sredini prvog stavka $i$ priprema temu fuge $u$ inverziji, koja dominira drugim dijelom stavka. Akordu $E$-Gis-H-D data je važnost pojavljivanjem njegovih komponenata u relativno dugačkim notnim vrijednostima (na važnost ovog sklopa podsjeća nas i njegova pojava nešto kasnije u I, 70, pr. 7e), a prelazak na sklop $G-B-D-F-A$, gdje su neke od komponenata u kraćim vrijednostima $u$ odnosu na prethodni, pokazuje i manju strukturnu važnost ovog kasnijeg. Na tako pređenom putu se kao zvučni događaji momentalnog značaja, bilo kao sazvuci ili kao sazvuci uz minimalnu horizontalno razlaganje, pojavljuju slične strukture terci (pr. 7c, d) te se tako može tvrditi da je

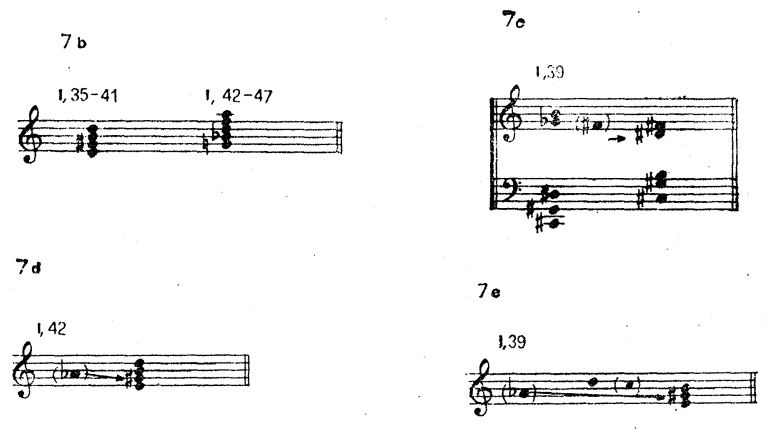

kompletno tkivo ovih nekoliko taktova stvoreno "cvjetanjem", otvaranjem iznutra prema vani jednog akordskog sklopa u kojem se njegovi vertikalni elementi prožimaju sa mogućnostima horizontalnog razmještanja tih istih elemenata u različite visinske registre. Sklop, kao što je bilo rečeno, najavljuje značajnu tematsku promjenu, pojavu početnog dijela teme $u$ inverziji (pr. 8a, b). Od ovog mjesta nadalje se tema pojavljuje i u $P$ i u

${ }^{11} \mathrm{Z}$ potvrdu o svjesnom preuzimanju Lisztovih ideja usp.: N. Rimsky-Korsakov, My Musical Life, New York, 1942, str. 78.

${ }_{12}$ Tako naprimjer Alfredo Casella u Devet komada za klavir op. 24 iz 1914. 


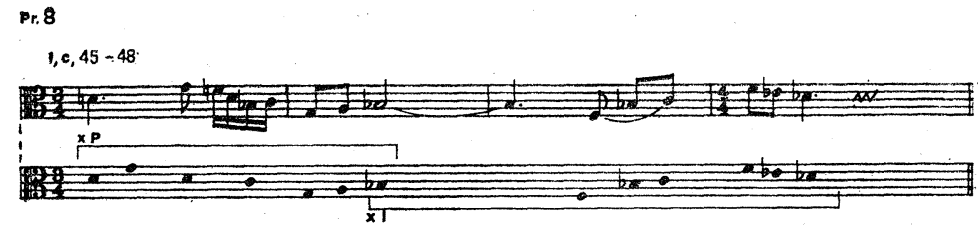

I formi, pa se na kombinaciji ovih dvaju njenih vidova zasniva i stretta (I, 73 i dalje). Stretta u zgusnutoj formi rezimira čitav argument stavka i u njegovim završnim taktovima (I, 76-86, pr. 9a) do kraja osmišljava neke elemente koji su ranije $u$ toku stavka bili tek naznačeni:

1. Pristup finalisu $D$ obavljen je uz pridavanje posebnog značaja tonu $C$. Ovo je potpuno razumljivo kad se ima $u$ vidu izvor inspiracije Slaven-
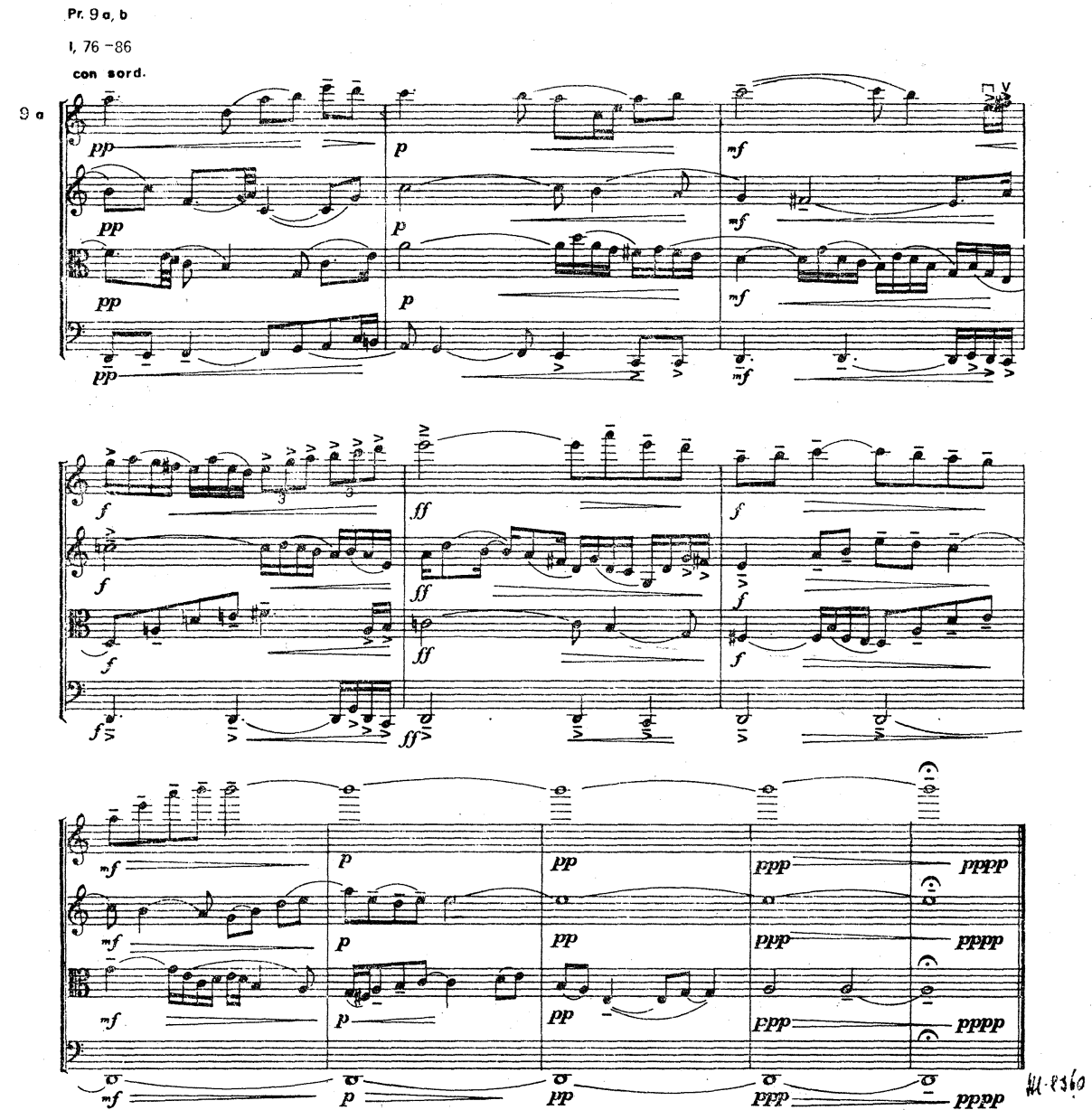
skog koji se nalazi u monodijskoj folklornoj muzici. Pristup finalisu $u$ toj muzici je uvijek linearan, te je izveden preko jednog od dvaju mogućih susjednih tonova: $E$ ili $C$. Važnost tona $E$ već je ranije podertana u taktovima oko sredine stavka, a sada je na kraju stavka i $C$ dobio svoju punu važnost. Tek sada je moguce shvatiti posebni naglasak na kadencnoj strukturi $G-C$ koja implicitno pridaje važnost tonu $C$ u kosturu teme (pr. 1b): ono što je na početku naznačeno tek $u$ jednom dubljem konstruktivnom sloju, izbija u melodijski prvi plan na zaključku.

2. Završni sazvuk stavka je $D-A-E-H$ (pr. $9 \mathrm{a}, \mathrm{b}$ ), to jest niz od tri superponirane kvinte. Prva violina se završnim retoričkim gestom postepeno

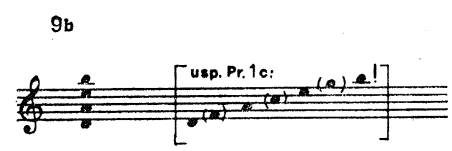

uzdiže do tog vrlo istaknutog tona, te se tako tek $u$ završnim taktovima stavka ispunjava nagoviještena mogućnost petog trozvuka, ili treće potpune kvinte, iz modela $y$ konačnim dodavanjem tona $H$.

\section{Drugi stavak (II)}

Zvuči možda kao reductio ad absurdum ako se kaže da drugi stavak zapravo ne donosi ništa tematski novo, nego samo vješto i ubjedljivo koristi modele i konstruktivne principe koji se pojavljuju već u prvom stavku. Slavenski je i u drugim svojim djelima pokazao da vješto vlada tehnikom melodijske varijacije te da dodavanjem ukrasnih i prolaznih tonova, kao i obrnutim postupkom, reduciranjem prvobitno razvijenije linije na njen osnovni obris, uspijeva da stvori priličnu prividnu raznolikost. Taj postupak dolazi osobito do izražaja $u$ formiranju prve od dvaju tematskih skupina koja su dale povoda da se drugi stavak okarakterizira kao sonatni. Tonalni centar te skupine je $A$, a njen melodijski sadržaj, jasno naznačen već $u$ II, a, $1-3$ zapravo potječe iz završnih taktova prvog

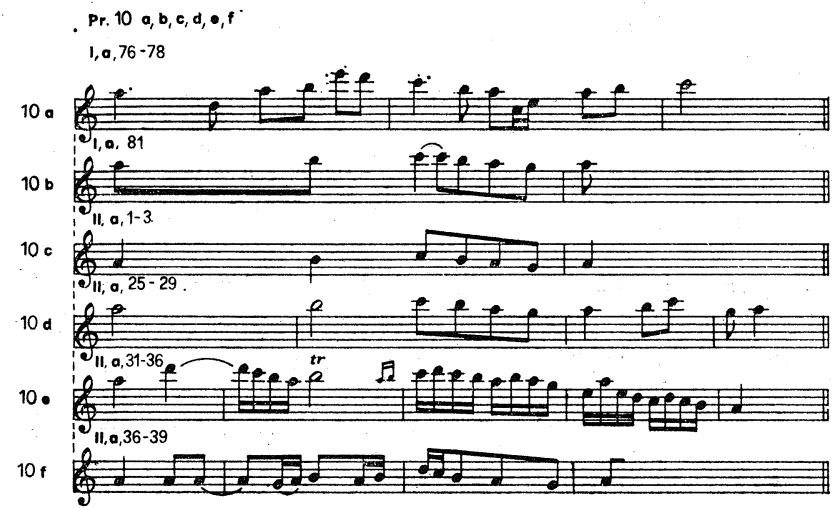


stavka gdje je originalno izveden iz konture početne fraze Kvarteta $u$ njenoj $I$ formi (pr. 10a, b). Drugi stavak donosi nekoliko novih varijacionih mogućnosti (pr. 10 c-f), a primjeri ovdje navedeni nikako ne iscrpljuju sve mogućnosti na koje se u toku stavka može naići, nego samo ukazuju na princip kojeg se Slavenski držao.

Tonalni centar druge skupine, koja odgovora "drugoj temi" sonatnoga stavka je $E$, što je naročito i naglašeno figuracijom (H-D-Fis-A)-(E-H-E) u II, 72-73. Nakon jednog pripremnog dijela (II, 74-80) najizrazitiji tematski materijal nalazi se $u$ II, a, 81-89 uz ponavljanje $i$ variranje $u$ daljnjim taktovima (pr. $11 \mathrm{a}, \mathrm{b}$ ). Lako je uočiti da tema zapravo nije nova,

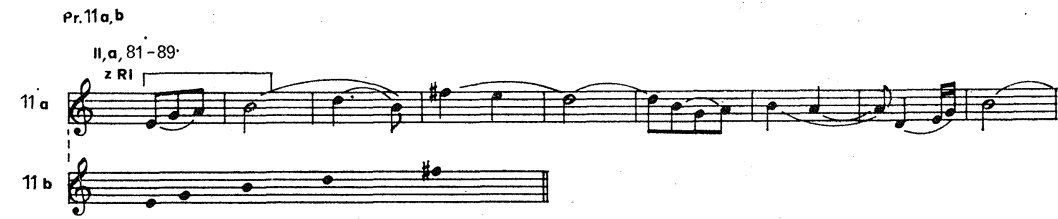

nego nanovo linearno varirani model $y$. Taj model će se kasnije, $u$ dijelu koji donekle ima ulogu reprize, pojaviti nešto proširen i transponiran za smanjenu kvintu naviše (pr. 12 a, b). Prava repriza druge teme, ako se o njoj uopće može govoriti, pojavljuje se u II, 236.

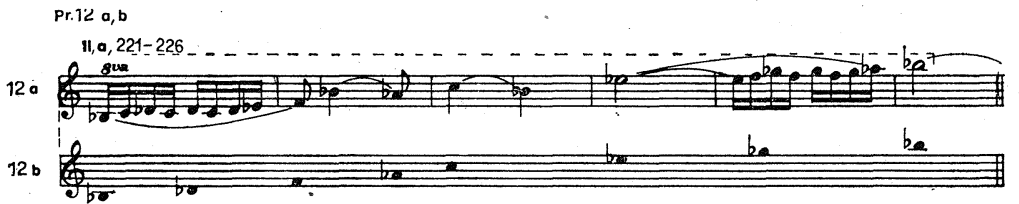

Početni motiv «druge teme« (pr. 11a) zaslužuje posebnu pažnju. Nalazimo ga nagoviještenog već na kraju prvog stavka: najprije u I, a, 79 a zatim u I, c, 84-85. U prvom slučaju to je $z R I$, a u drugom $z^{1} R I$, a sada se $\approx R I$ ponovo pojavljuje kao karakteristični strukturni i slušni elemenat teme, koja zbog nedostatka polustepenog pomaka $u z i z^{1}$ dobiva izvjestan pentatonički karakter. Transformacije modela $\boldsymbol{z}^{1}$ mogu se slijediti kao pozadina $u$ pojedinim odsječcima melodijske linije gdje je uvođenjem prolaznih tonova pentatonika $u$ stvari napuštena (pr. 13 a, b). Po uzoru na

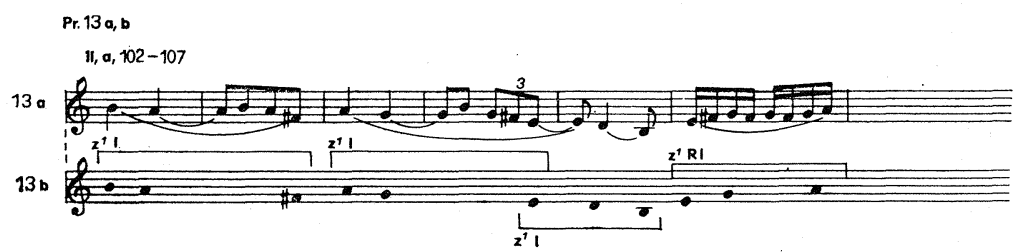

proces $\mathrm{u}$ prvom stavku, naslućuje se tendencija da se linearni model iskoristi i kao vertikalna struktura, makar se radilo i o kratkotrajnom pojavljivanju jednog zvučnog sklopa (pr. 14). U prva tri slučaja (II, 108, 
$110,112)$ pojavljuju se $u$ vertikalnom razmještanju tonovi iz $z P, u$ II, 113 se pojavljuje nepotouni $z P$, a u II, $114 z^{1} R I$. Interesantna varijanta transformacije horizontalnog elementa $u$ vertikalni nalazi se $u$ II, 235 (pr. 15) i ukazuje na naklonost kompozitorovu da princip kumulativne harmonije primijeni i na motivski rad. Istina $u$ Kvartetu je ta primjena tek naslucena sa vremena na vrijeme (tako u II, 286-290 i II, 321) i tek ce analize kasnijih djela Slavenskog pokazati do koje mjere je on uspio razviti ovaj princip.
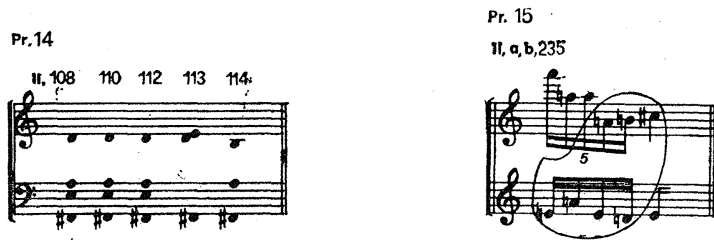

Povremenim pojavljivanjem transformacija modela $x$ i uz nešto dosljednije ponavljanje materijala iz I u II, 293-305, pojačan je osjećaj cikličke kompletnosti. Kompletnost je postignuta ne samo ponavljanjem i kombiniranjem materijala iz I i II, što je prirodno i očekivati, nego i potvrđivanjem principa koji je prihvaćen već $u$, da se prilaz tonici obavi ne harmonski preko dominante nega linearno, preko njenih dvaju susjednih tonova. Kako je unatoč odstupanjima tonski centar II $A$, prirodno je očekivati da tonovi $H$ i $G$ dobiju odgovarajući značaj. (U melodijskom razvoju cjelostepeni pomak od subtonike ka tonici uvijek ima prvenstvo nad polustepenim, koji ostaje vezan uz harmonski strukturni aspekt.) Slično kao i u slučaju prvog stavka, tonu $H$ je zaista data važnost već znatno prije završetka stavka, u II, d, 264-275 jeđnom pažljivo konstruisanorn

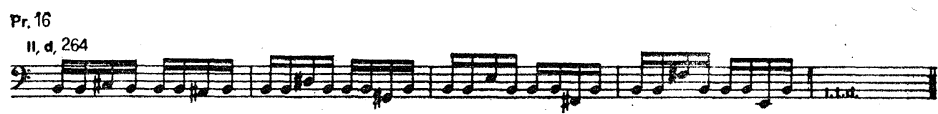

linijom (pr. 16). Kasnije, $G$ dolazi do izražaja u II, d, 365-390 kao važna linearna prolongacija tona $A$ (pr. 18), dok se u vertikalnoj kombinaciji miješaju trozvuk na $A$, četverozvuk na $E$ i naslućuje trozvuk na $H$ (osobito u II, 385-386), neposredno pred konačno ukidanje napetosti nastupom finalnog trozvuka na $A$ u II, 392. (Pr. 17).

Odigravši ovu značajnu melodijsku ulogu, ton $G$ opravdava tako važr nost koja mu je data kao prolaznom događaju u strukturi početne teme Kvarteta gdje je stupio u kauzalni odnos i prema $C$ i u manje naglašenoj mjeri prema $A$. Taj posebno naglašeni $C$, opet, vidimo i kao prilazni ton $D$-u u pravom stavku, i što je osobito zanimljivo, kao ishodište čitave jedne tonske oblasti $u$ harmonskoj strukturi drugog stavka.

Iako je ranije bilo rečeno da je $A$ tonski centar drugog stavka, ova se tvrdnja mora sada kvalificirati napomenom da je $A$ samo jedan, doduše važniji od centara. Harmonska shema drugog stavka posebno je zanimljiva 

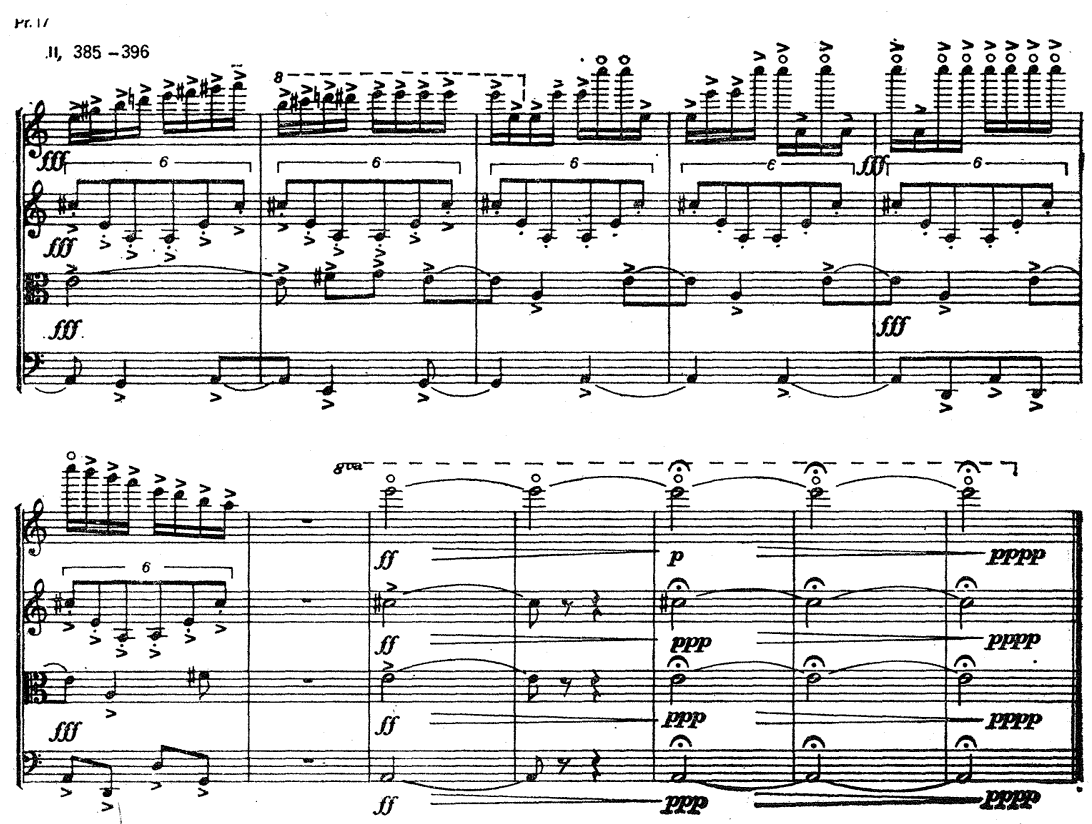

.Pr. 18

ข. d. $369-396$

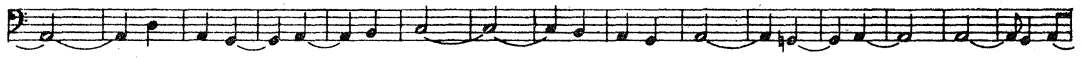

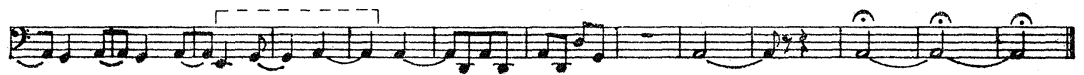

jer otkriva pokušaj Slavenskog da harmonski argument zasnuje na dva koegzistirajuća tonalna nivoa. Jedan od njih uporno potvrđuje svoju egzistenciju naglašavanjem relacija $A-E-A$, dok se drugi od njega udaljava.

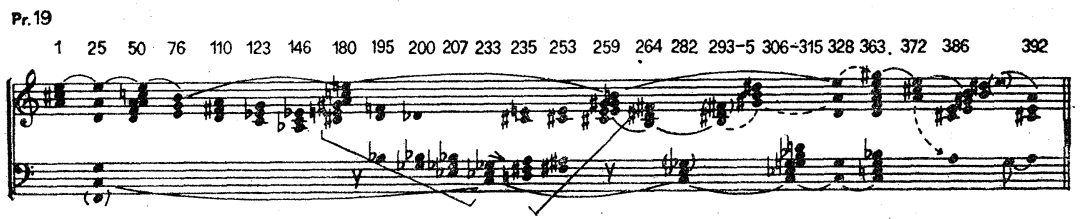

(Pr. 19) U skiciranom dijagramu harmonskog procesa visina je relativna: gornji sistem pokazuje glavnu relaciju stavka $(A-E-A)$ i neke od prolaznih događaja, dok donji sistem omogućuje da se demonstrira udaljavanje drugog nivoa i važnost tona $C$ kao sekundarnog cilja. (Dijagram nema funkciju prikaza srednjeg strukturnog plana Schenkerovog tipa, nega samo naznačava tonske oblasti, bez namjere da pokaže tačno vođenje strukturnih glasova.) $U$ toku stavka dva se nivoa prepliću $i$ često proces $u$ 
jeđnom nivou biva napušten, da bi se nastavio tek pošto je napravljen excursus $\mathrm{u}$ drugi nivo. Harmonski pokret je često zasnovan na jednostavnom principu da jedan od tonova iz jednog sazvučja postaje izvorištem novog tonskog centra, te tako dva tonalna područja imaju nešto što ih veže, a da ne stupaju ni u kakav međusobni funkcionalni odnos. Zanimljiv je progres između taktova 130 i 233 , te 235 i 259 koji pokazuje postojanje modela $y$ na vrlo dubokom strukturnom planu.

Na kraju prvog stavka je tonski fokus bio proširen u sazvuk triju superponiranih kvinti (pr. 9b), a konačni cilj drugog stavka je vraćanje na njegov središnji dio (trozvuk A-Cis-E). Da bi osigurao harmonsku energiju i njome nadomjestio izvjesni nedostatak melodijskog razvoja, Slavenski u drugom stavku najprije proširuje prostor još i više (takt 25) a onda pred kraj stavka ponovo uvodi ovu široku tonsku lepezu, sada još dramatičnije proširenu (takt 362). Time je uspio da na čas ujedini oba tonska nivoa a uzbuđenje tog čina podcrtao je dinamičkim oznakama Più presto (balcanico) i Prestissimo possibile. Ovo ubrzanje ne predstavlja, prema tome, samo porast ritmičkog intenziteta pred završetak djela nega ima svoj smisao u širem okviru čitavog stavka.

Međusobna tijesna povezanost različitih strukturnih elemenata i logično slijeđenje i razvijanje mogućnosti nagoviještenih već na samom početku djela su sa kompozicionog stanovišta najvažnije odlike ovog Kvarteta. Utisak spontanosti je zapravo dokaz da struktura nije nametnuta izvana, nego da izvire iz prirode motivskog i harmonskog materijala. Naravno, kompozicioni proces kojeg je Slavenski ovdje razvio sadrži i izvjesne opasnosti: ukrasne figure poput one tipa $(x)$ mogu lako ostati vanjski dekorativni elementi bez tješnje povezanosti sa tkivom muzičkog materijala, dok gomilanje akorada u pantonalni sklop može postati zvučna kulisa koja također poprima funkciju retoričarski praznog muzičkog gesta, odvojenog od logike muzičkog razvoja. I na jedno i na drugo naići ćemo u kasnijim djelima Slavenskog, no u svakom pojedinačnom slučaju treba te elemente procenjivati isključivo unutar struktura u kojima se pojavljuju i bilo bi nepravedno iskorištavati in za donošenje suviše uopćenih zaključaka.

Svjestan sam da će ovaj moj pristup Prvom kvartetu Slavenskog izazvati kritičke primjedbe. Pretpostavljam da će jedan od prigovora biti da sam $\mathrm{u}$ ovoj analizi suviše "racionalizirao" muziku Slavenskog, koja je, po općem uvjerenju tekla iz njegovog pera spontano i lako. U odgovoru na takvu primjedbu može se reći da proces nastajanja jednog djela nije identičan sa završenim djelom samim. Istina je da $u$ procesu stvaranja kompozitor ne mora biti racionalno svjestan svakog detalja niti svih implikacija djela, ali takvo stanje ni po čemu ne isključuje postojanje razvojne logike koja sprečava da se kompozicija raspadne u niz manje ili više nezavisnih muzičkih događaja. Pokušaj osvjetljavanja te logike, a ne traženje izvora individualnog nadahnuća, je bio cilj ovog priloga. 
SKRACENICE

$$
\begin{aligned}
& \text { I - prvi stavak } \\
& \text { II - drugi stavak } \\
& \text { a - 1. violina } \\
& \text { b - 2. violina } \\
& \text { c - viola } \\
& \text { d - violoncello }
\end{aligned}
$$

$P$ - primarna forma

I - inverzija

$R$ - retrogradna forma

$R I$ - retrogradna inverzija

Kod muzičkih primjera prvi simbol se odnosi na stavak, drugi na dionicu a broj na takt. Napr.: I, d, 28-32 - prvi stavak, dionica violoncella, taktovi 28-32. Ako nije navedena skraćenica za instrumenat, oznaka se odnosi na sve četiri dionice.

\section{SUMMARY}

The paper deals with the First String Quartet by the Yugoslav composer Josip Slavenski (1896-1955). When the piece was performed at the Donaueschingen Festival in 1924 it was enthusiastically received by the critics and brought international recognition to its author. Contrary to a tendency, noticeable in some Yugoslav writings on Slavenski, to portray him as an entirely independent mind, the paper points out some of the obvious links that exist between the music of Slavenski and that of his one-time teacher Kodály, and Béla Bartók. The analysis which follows explains the inner unity of the two-movement Quartet by demonstrating the importance of the features of the melodic foreground and harmonic background of the opening theme for the whole subsequent argument of the work. 